Natalia Paprocka

https://doi.org.10.26881/ae.2018.15.03

ORCID: 0000-0001-8178-8116

Uniwersytet Wrocławski

natalia.paprocka@uwr.edu.pl

\title{
Nie tak dawno temu we Francji... Rok 1968 i francuska rewolucja w dziedzinie książki obrazkowej ${ }^{1}$
}

Przełom lat sześćdziesiątych i siedemdziesiątych XX wieku to w Europie czas przemian społecznych i kulturowych, które wywarły wpływ również na sposób postrzegania dzieciństwa i na kształt całej kultury dziecięcej. Sophie Heywood mówi wręcz o dziecięcym wymiarze rewolucji 1968 roku (children’s '68), między innymi dlatego, że rok ten stał się mniej lub bardziej symboliczną cezurą w dziejach literatury dla dzieci i młodzieży w wielu krajach europejskich - w Niemczech, w krajach skandynawskich, we Włoszech czy we Francji (Heywood 2018).

Nad Sekwaną zmiany objęły przede wszystkim książkę obrazkową, dlatego badacze francuskiej literatury dla dzieci i młodzieży mówią o rewolucji - czy też odnowie - w odniesieniu do tego rodzaju publikacji (zob. Nières-Chevrel 2009: 50; Van der Linden 2013: 208; Prince 2015: 60-62). Jej inicjatorami i głównymi aktorami byli młodzi wydawcy, publikujący awangardowe książki dla dzieci, nierzadko określane mianem „wywrotowych” (subversifs) (Boulaire 2008). Takie oficyny jak Robert Delpire, Harlin Quist, Éditions des Femmes czy Le Sourire qui mord zaczęły wówczas wydawać książki obrazkowe dla młodych odbiorców, które odbiegały od dotychczasowych przyzwyczajeń czytelników zarówno z punktu widzenia formy, jak i podejmowanych tematów. Na pierwsze miejsce wysunęła się artystyczna wartość książek dla dzieci - ilustracja uzyskała w nich pełną autonomię i przestała być dodatkiem do tekstu. Literatura dla dzieci i młodzieży stała się terenem niezwykle intensywnych doświadczeń artystycznych, a jej celem nie było wyposażenie małego czytelnika w przydatną i konkretną wiedzę, lecz wykształcenie w nim

${ }^{1} \mathrm{O}$ francuskiej książce obrazkowej piszę również w monografii Sto lat przekładów dla dzieci $i$ młodzieży w Polsce. Francuska literatura dla młodych czytelników, jej polscy wydawcy i ich strategie (1918-2014) (Paprocka 2018: 118-126). 
wrażliwości na piękno, „wyrabianie oka” (éducation de l'œil) (Nières-Chevrel 2009; Beckett 2015).

Nurt awangardowej książki obrazkowej z przełomu lat sześćdziesiątych i siedemdziesiątych odegrał znaczącą rolę w rozwoju francuskiej literatury dla dzieci i młodzieży, ponieważ twórczy ferment, który mu towarzyszył, nadał impet dyskusji nad pojęciami literatury dla dzieci i dzieciństwa we Francji, a w ślady niezależnych małych oficyn poszły wkrótce duże wydawnictwa francuskie, trwale modyfikując swoją ofertę.

\section{Nieznane w Polsce}

Nowatorskie książki obrazkowe z przełomu lat sześćdziesiątych i siedemdziesiątych, które zrewolucjonizowały francuską literaturę dla dzieci i młodzieży, do Polski jednak nigdy nie dotarły. Nasza Księgarnia, która po drugiej wojnie światowej przez pół wieku była głównym wydawcą książek dla dzieci i młodzieży, opublikowała tylko jedną książkę tego nurtu - w 1968 roku pod tytułem Ładny kwiat! ukazał się polski przekład książki C’est le bouquet! Claude’a Roy z ilustracjami Alaina Le Folla. Był to jednak ewenement na polskim rynku, a francuskie książki obrazkowe z okresu rewolucji obyczajowej pozostały w Polsce całkowicie nieznane.

$\mathrm{Na}$ wieloletnie pomijanie francuskiej książki obrazkowej w imporcie literatury dla młodych czytelników wpływ miała w dużej mierze specyfika rynku wydawniczego w Polsce Ludowej. Powszechne w tym okresie było opatrywanie przekładów literatury obcej ilustracjami polskich artystów współczesnych (zob. Paprocka 2018: 282-284), co wiązało się z wysokim poziomem, który reprezentowała tzw. polska szkoła ilustracji (zob. Wincencjusz-Patyna 2008; Cackowska, Wincencjusz-Patyna 2017), jednak sprawiało też, że nie docierała do Polski zagraniczna książka obrazkowa, której integralną część stanowiły przecież ilustracje.

Dodatkowo ze względu na uwarunkowania ideologiczne preferowano inne kierunki zapożyczeń literackich, a współczesną literaturę francuską postrzegano jako tradycyjną i płytką. Świadczą o tym zarówno słowa Krystyny Kuliczkowskiej z końca lat pięćdziesiątych: „[...] współczesna literatura francuska dla młodzieży nie zasługuje na miano nowatorskiej” (Kuliczkowska 1957: 1383), jak i pochodząca z kolejnej dekady wypowiedź Olgi Nowakowskiej: „[...] obecnie zaznacza się w niej przesadna supremacja elementu rozrywkowego i paniczna ucieczka przed poważniejszymi problemami" (Nowakowska 1968: 156).

Obraz francuskiej literatury dla dzieci i młodzieży, który mogli tworzyć sobie polscy czytelnicy na skutek wyborów wydawców i takich opinii krytyków, nie był jednak zgodny z rzeczywistością. W niniejszym artykule chciałabym to udowodnić, przybliżając założenia i dokonania nieznanego w Polsce nurtu francuskiej awangardowej książki obrazkowej z lat sześćdziesiątych, siedemdziesiątych i osiemdziesiątych XX wieku. 


\section{Początki książki obrazkowej we Francji}

We Francji status książki obrazkowej (fr. album) jest odmienny niż w Polsce. O ile nad Wisłą gatunek ten długo był marginalizowany (zob. Cackowska 2009/2010, 2017), o tyle nad Sekwaną od początku cieszył się on uznaniem, w związku z czym termin album jest $\mathrm{w}$ powszechnym użyciu i nie jest obciążony negatywnymi konotacjami².

Za czas narodzin książek obrazkowych we Francji uważa się drugą połowę XIX wieku (Nières-Chevrel 2009: 42; Van Der Linden 2009: 25). W 1860 roku pod tytułem Pierre l'Ébouriffé (dosł. Rozczochrany Piotr) ukazał się francuski przekład książki obrazkowej Heinricha Hoffmanna Der Struwwelpeter (1845-1847), a wkrótce powstawać zaczęły pierwsze francuskie utwory tego rodzaju, na przykład Mademoiselle Marie Sans-Soin (1867, Panienka Maria Niedbała) rysownika Bertalla, czy Une journée de Mademoiselle Lili (1862, Dzień panienki Lili) wydana przez Hetzela $\mathrm{z}$ własnym tekstem (pod pseudonimem P.J. Stahl) z ilustracjami Duńczyka Lorenza Frølicha.

Okres międzywojenny to we Francji czas powstania nowoczesnej książki obrazkowej (Nières-Chevrel 2009: 46; Lévêque 2011: 163). Manifestem awangardowego podejścia do gatunku była wydana $\mathrm{w}$ dużym, niemal kwadratowym formacie książka Macao et Cosmage ou l'expérience du bonheur (1919, Macao i Cosmage, czyli doświadczenie szczęścia) malarza Édy-Legranda, w której ilustracja zdecydowanie przeważała nad tekstem. Jej bohaterowie, białoskóry Macao i czarnoskóra Cosmage, żyją szczęśliwie na nieistniejącej na mapach rajskiej wyspie - do czasu przybycia kolonizatorów. Równie nowatorska była seria książek obrazkowych o słoniu Babarze malarza Jeana de Brunhoffa, zapoczątkowana przez Histoire de Babar, le petit éléphant (1931, wyd. pol. Przygody małego słonia Babara, 2012). Tworzące ją tomy były dużego formatu $(37 \times 27 \mathrm{~cm})$, z całostronicowymi ilustracjami, w które wpleciony został wykonany pisanką tekst.

Do rozwoju francuskiej międzywojennej książki obrazkowej przyczynił się też Paul Faucher, zwolennik reformatorskiego ruchu pedagogicznego nowego wychowania (éducation nouvelle). Znany jest on pod pseudonimem Père Castor (Ojciec Bóbr), który pochodzi od imienia bohatera zapoczątkowanej przez niego w 1931 roku serii „Albums du Père Castor” (Książki obrazkowe ojca Bobra). Tworzące ją cienkie, zszywane książeczki w miękkiej oprawie sprzedawano po przystępnej cenie, bo książka obrazkowa w koncepcji Fauchera miała być nie tyle luksusowym, wyrafinowanym przedmiotem sztuki, ile kreatywnym narzędziem służącym do nauki dzieciom, postrzeganym jako samodzielne i twórcze jednostki. Faucher zgromadził wokół siebie grupę znakomitych pisarzy, pedagogów

${ }^{2}$ Różnice w rozumieniu obu pojęć szerzej omówiłam podczas konferencji „Wokół terminologii: teoria, dydaktyka i praktyka" (Wrocław, 8-9 marca 2018) w referacie Polski termin „książka obrazkowa” a francuski „album”: kontrastywne mikrostudium ekwiwalencji częściowej. 
i ilustratorów z Francji, Niemiec, Czechosłowacji, Związku Radzieckiego, ale także z Polski - współpracowała z nim Franciszka Themerson ${ }^{3}$.

\section{Rewolucja w dziedzinie książki obrazkowej}

Po wojnie francuska książka obrazkowa pozostawała jeszcze dość tradycyjna, jednak od początku lat sześćdziesiątych wywodzący się z inteligenckiego mieszczaństwa młodzi rodzice zaczęli się upominać o ambitniejszą twórczość dla dzieci. Przestały im wystarczać serie książek obrazkowych przeznaczonych dla masowego odbiorcy i gotowi byli na duże zmiany. Ich oczekiwania miały związek z ogólnymi nastrojami społecznymi, które panowały we Francji pod koniec lat sześćdziesiątych, i z narastającą w tym czasie falą rewolucji obyczajowej. Jej punktem kulminacyjnym stały się trwające od maja do lipca 1968 roku paryskie rozruchy studenckie i robotnicze, które zakończyły się strajkiem generalnym i miały dalekosiężne skutki dla życia kulturalnego, politycznego i gospodarczego kraju (Agulhon, Schor, Nouschi 1995: 223-251).

\section{Robert Delpire}

Pierwszymi zwiastunami zmian w literaturze dla dzieci i młodzieży były teksty pisarzy nowego pokolenia i ilustracje młodych, awangardowych artystów plastyków (między innymi Nicole Claveloux, Claude Lapointe, Joëlle Boucher, Éléonore Schmid, Philippe Fix, Fernando Puig Rosado) publikowane w nowo powstałych czasopismach dla młodych czytelników (między innymi „Pomme d'Api”, od 1966; „Okapi”, od 1971; „’’aime lire”, od 1977), a także książki publikowane już od połowy lat pięćdziesiątych przez niezależnego wydawcę Roberta Delpire’a. Wśród nich była na przykład humorystyczna, wydawana w różnych formatach książka Les larmes de crocodile (1955, Krokodyle łzy), którą w całości stworzył André François, czy wysmakowana C'est le bouquet! (1964, wyd. pol. Ładny kwiat!, 1968) z tekstem Claude’a Roy i ilustracjami Alaina Le Folla. Wydawca zapoczątkował też w 1967 roku serie „Actibom” i „Multibom”, w których ukazywały się wielkoformatowe $(45 \mathrm{~cm})$ książki łączące w sobie cechy książek aktywnościowych, popularnonaukowych i narracyjnych (Nières-Chevrel 2009: 49-50; Piquard 2010).

Właściwym początkiem rewolucji stało się jednak wydanie przez Delpire’a w 1967 roku tłumaczenia książki obrazkowej Maurice'a Sendaka Where the Wild Things Are (1963) pod francuskim tytułem Max et les Maximonstres (wyd. pol. Tam, gdzie żyja dzikie stwory, 2014). Choć książka została przyjęta przez krytyków

\footnotetext{
${ }^{3}$ Jej ilustracje znalazły się w dwóch książkach z serii wydanych przez Flammarion w Paryżu w 1939 roku autorstwa May d'Alençon - Tricoti Tricota oraz Tout en soie, cochon aérodynamique.
} 
początkowo dość ostrożnie, to wśród francuskich czytelników już po pierwszym wydaniu zyskała sporą popularność, a po wznowieniach - status książki kultowej (Nières-Chevrel 2010).

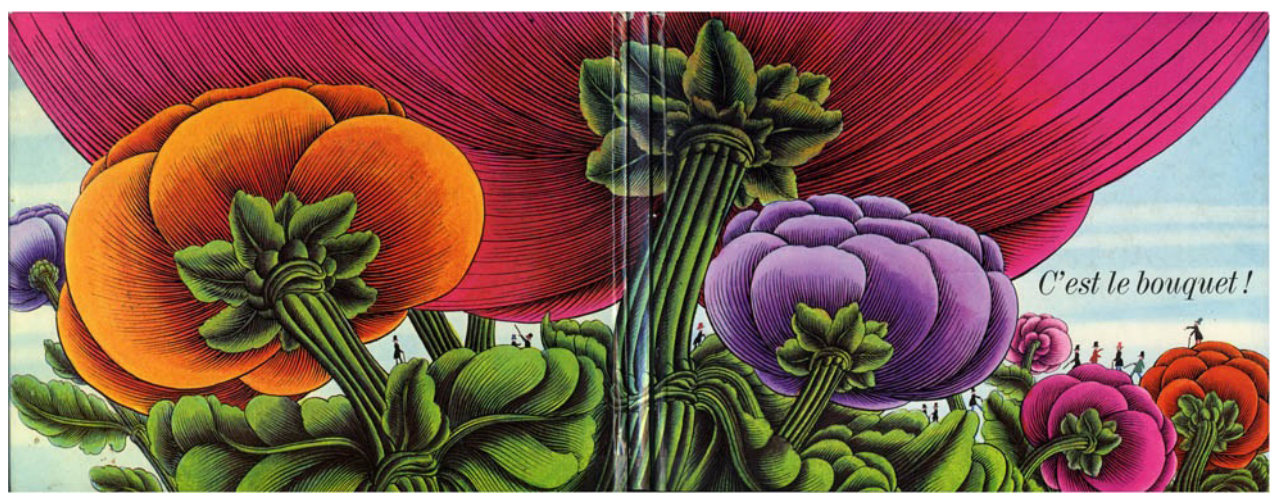

Il. 1. Ilustracja Alaina Le Folla na pierwszej i czwartej stronie okładki książki C'est le bouquet autorstwa Claude'a Roy z 1964 roku

\section{Harlin Quist i François Ruy-Vidal}

Kolejni „rewolucjoniści” to François Ruy-Vidal i amerykański wydawca Harlin Quist, którzy w 1967 roku zarejestrowali w Paryżu spółkę pod nazwą Éditions Harlin Quist. Sześcioletnią współpracę Ruy-Vidal określił jako „pobudzającą i wzmacniającą, prowokującą i decydującą, zarówno dla [niego samego], jak i dla francuskich autorów, ilustratorów i wydawców zaskoczonych oryginalnością nowych propozycji"4 (Piquard 2005: 300). Oryginalność Quista i Ruy-Vidala wynikała $\mathrm{z}$ tego, że negowali oni istnienie odrębnych zasad rządzących sztuką dla dzieci i odrębnych kryteriów jej oceny, co Ruy-Vidal wyraził następująco:

Nie ma kolorów dla dzieci,

Są kolory.

Nie ma grafiki dla dzieci,

Jest grafika, która jest

bezpośrednim językiem międzynarodowym.

Nie ma literatury dla dzieci,

Jest Literatura ${ }^{5}$.

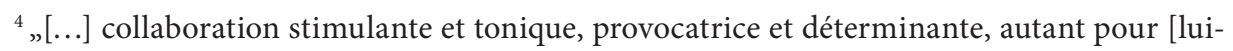
même] que pour les auteurs, illustrateurs et éditeurs français surpris par l'originalité des propositions nouvelles" (tłumaczenie tego i pozostałych cytatów na język polski - N.P.).

${ }^{5}$ „Il n'y a pas de couleurs pour enfants / Il y a les couleurs / Il n'y a pas de graphisme pour enfants / Il y a le graphisme qui est / Un langage international immédiat. / Il n'y a pas de littérature pour enfants / Il y a la littérature”. Sformułowane przez Ruy-Vidala zasady przytaczane są 
Ruy-Vidal, który również pisał i tłumaczył teksty oraz był pomysłodawcą wielu opublikowanych przez wydawnictwo książek, pragnął dać dzieciom „książki odważne, to znaczy trochę agresywne”, mówiące „o śmierci, o wojnie, o prawdziwych, realnych rzeczach, o tym, co jest nie w porządku”' (Soriano 1975: 462). Te założenia podzielał Quist, który w 1998 roku przypomniał, jak razem ze swoim wspólnikiem rozumieli rolę książki dla dzieci: „Dzieciństwo trwa krótko. Wielu wydawców uważa, że młode lata powinno się chronić, że życie przyniesie wystarczająco szybko swój korowód kłopotów i że książki przeznaczone dla dzieci muszą uspokajać i odprężać. My myślimy odwrotnie. [...] Uspokajanie jest przeciwieństwem stymulacji. A dziecko potrzebuje stymulacji, zachęty do refleksji" (Piquard 2005: 299-300).

Z taką koncepcją literatury dla dzieci Ruy-Vidal i Quist w latach 1967-1972 wprowadzili na rynek ponad 30 książek obrazkowych ujętych w serię „Un livre d'Harlin Quist” (Książka Harlina Quista), innowacyjnych zarówno z punktu widzenia grafiki, jak i podejmowanych tematów. Publikowano w niej utwory autorów niecodziennych, niekojarzących się z odbiorcą dziecięcym, którym propozycję napisania książek dla dzieci składał Ruy-Vidal (Vergez-Sans 2016). Na prośbę wydawcy Eugène Ionesco napisał „bajki dla dzieci poniżej trzeciego roku życia” (1968, 1970, 1971), a Marguerite Duras w Ah! Ernesto (1971) opisała chłopca oznajmiającego rodzicom po pierwszym dniu spędzonym w szkole, że tam nie wróci, bo uczą go tego, czego on nie wie.

Współpracę z Ruy-Vidalem szybko podjęli awangardowi francuscy ilustratorzy nowego pokolenia, związani nierzadko ze światem reklamy, inspirujący się nowatorskimi wówczas nurtami surrealizmu, hiperrealizmu, psychodeli i pop-artu. Byli wśród nich przede wszystkim Bernard Bonhomme, Danièle Bour, Nicole Claveloux, Philippe Corentin, Patrick Couratin, Étienne Delessert, Henri Galeron, Maurice Garnier czy Claude Lapointe. Interpretowali oni teksty autorów współczesnych (na przykład Alala: les télémorphoses, 1970, Alala: telemorfozy), ale też dawnych. Nicole Claveloux w 1970 roku zilustrowała z mistrzostwem godnym Gustave’a Dorégo bajkę Sophie de Ségur La forêt des lilas (Las lilii) z $1856 \mathrm{roku}$, a Claude Lapointe zaproponował w 1972 roku "hipisowską adaptację” (Piquard 2005: 299) klasycznej książki obrazkowej Heinricha Hoffmana Der Struwwelpeter z 1845 roku, w której nieposłuszeństwo podniósł do rangi cnoty.

w różnym brzmieniu w zależności od źródła. Wersja, którą cytuję, pochodzi z korespondencji prywatnej z wydawcą, który pisze, że w takiej właśnie formie ukazały się one w katalogu działu książki dziecięcej Grasset-Jeunesse z przełomu listopada i grudnia 1973 roku.

${ }^{6}$ „En donnant aux enfants des livres courageux, c'est-à-dire un peu agressifs, on prend le courage de leur parler de la mort, de la guerre, des choses vraies, réelles, de ce qui ne va pas".

${ }^{7}$ „Le temps de l'enfance est court. Beaucoup d'éditeurs prétendent que ces jeunes années doivent être protégées, que la vie viendra bien assez tôt apporter son cortège de complications et que les livres destinés aux enfants doivent apaiser et rassurer. Nous pensons le contraire. [...] Calmer est le contraire de stimuler. Or l'enfant a besoin d'être stimulé, d'être incité à réfléchir". 


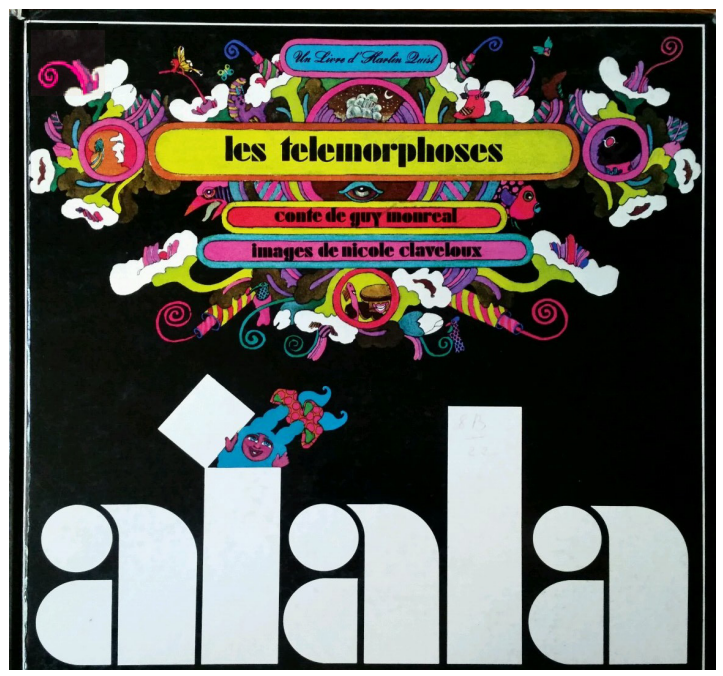

Il. 2. Okładka książki Alala: les télémorphoses Guya Monreala ilustrowanej przez Nicole Claveloux z 1970 roku

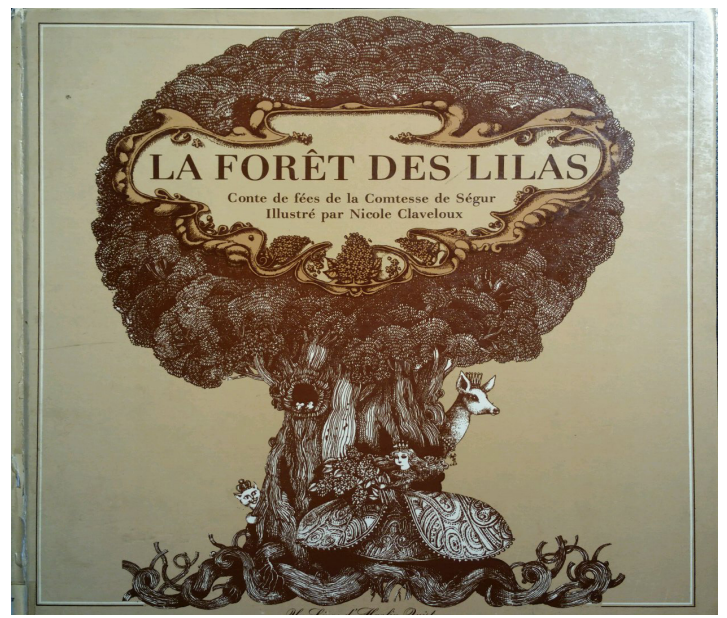

Il. 3. Okładka książki La forêt des lilas Sophie de Ségur ilustrowanej przez Nicole Claveloux z 1970 roku

Kontrowersyjne książki publikowane przez Ruy-Vidala i Quista stały się przedmiotem gorących dyskusji we francuskiej prasie i telewizji. Obu wydawcom zarzucano, że ich publikacje są przeznaczone dla dorosłych, a nie dla dzieci. Teksty uważano za zbyt trudne i zbyt wyszukane, a ilustracje - za zbyt „modernistyczne”, zbyt przesiąknięte surrealizmem i awangardą, dalece odbiegające od kryteriów prostoty, „ładności” i rozpoznawalności, którymi powinny cechować się książki dla najmłodszych (Soriano 1975: 459-465). Znajdująca się w szeregach oponentów znana francuska pediatra i psychoanalityk Françoise Dolto uważała wręcz, 
że niektóre ilustracje mogą świadczyć o „tłumionych obsesjach seksualnych”8 ich autorów. Sandra Beckett (2012) zalicza książki publikowane przez oficynę Harlin Quist do tzw. crossover literature, czyli literatury przełamującej bariery wiekowe, podobającej się zarówno dorosłym, jak i dzieciom.

\section{Éditions des Femmes}

Po wydarzeniach maja 1968 roku i na początku lat siedemdziesiątych XX wieku na francuskim rynku wydawniczym nastała prawdziwa "wiosna wydawców” (Bouavaist, Boin 1989), bo pojawiło się mnóstwo małych, pionierskich oficyn, z których wiele publikowało również lub wyłącznie książki dla dzieci.

W 1972 roku z inicjatywy członkiń francuskiego Ruchu Wyzwolenia Kobiet (Mouvement de libération des femmes) powstała oficyna Éditions des Femmes (Wydawnictwo Kobiet), w którym pracowały same kobiety. W latach 1975-1976 jej nakładem ukazała się seria książek obrazkowych „Du côté des petites filles” (W stronę dziewczynek), której nazwa stanowiła nawiązanie do głośnego we Francji feministycznego eseju Dalla parte delle bambine Eleny Belotti z 1973 roku. Książki obrazkowe z tej serii przeszły do historii feminizmu, bo prezentowały inne spojrzenie na kwestię płci i roli kobiety w społeczeństwie. Były to między innymi tłumaczone z włoskiego Rose bombonne (1975, Cukierkowy róż) i Clémentine s'en va (1976, Clémentine odchodzi) Adeli Turin i Nelli Bosni.

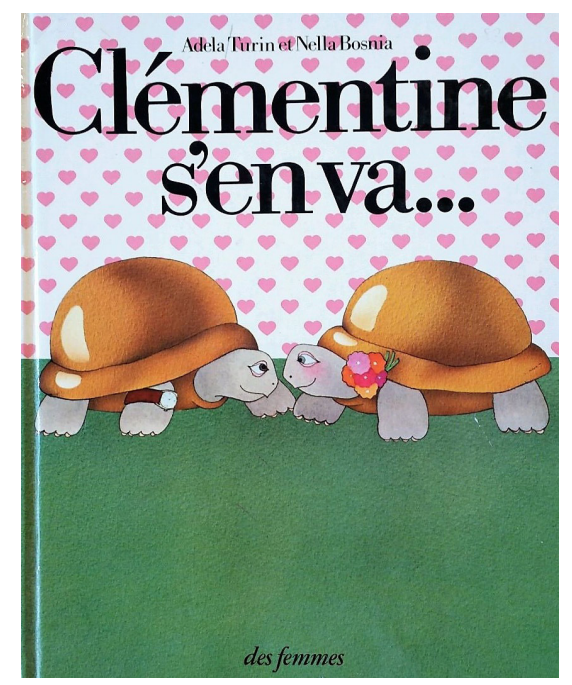

Il. 4. Okładka książki Clémentine s’en va Adeli Turin i Nelli Bosni z 1976 roku

\footnotetext{
${ }^{8}$ „Ce ne sont que désirs terrifiants, désirs informulés, plaisirs informulés, plaisirs inachevés, obsessions sexuelles refoulées” (Dolto 1972: 139).
} 


\section{Le Sourire qui mord}

Kolejnym „rewolucyjnym” wydawcą był Christian Bruel, który w 1975 roku założył wydawnictwo Le Sourire qui mord (dosł. Uśmiech, który gryzie). Jego pierwszą książką była Histoire de Julie qui avait une ombre de garçon (1976, Historia Julii, która miała cień chłopca) napisana przez Bruela wraz z Anne Galland. Na liście trudnych tematów poruszanych w książkach obrazkowych dla dzieci pojawiła się tym samym szeroko pojęta odmienność. O wyjątkowości książki zdecydował jednak nie tylko temat, ale też charakterystyczne, czarno-białe rysunki Anne Bozellec.

W biuletynach wydawniczych Bruel wyjaśniał, że celem oficyny miało być zerwanie „z książkami [...] których morał każe wrócić do szeregu po przejściowych buntach"9 (Piquard 2005: 317). Wydawca chciał zaoferować czytelnikowi alternatywę poprzez stworzenie „książki innej, książki przełomowej, zarówno dla dzieci, jak i dla dorosłych, książki, w której każdy, niezależnie od wieku, znajdzie pożywkę do marzeń, do rozmyślań, do buntu, książki, która nie będzie już udawała niewinnej!”10 (ibidem: 316). Bruel deklarował również: „Będziemy mówić o czułości, strachu, przyjemnościach, rozwodzie, bólu, nienormalności, wodzie, ogniu, życiu, śmierci... a nie o grzecznych motylkach czy o brzydkich kaczątkach"11 (ibidem: 317). Bohaterami książek dla dzieci miały być postaci „gęste, konfliktowe, niejednoznaczne, niepokorne, umiejące wątpić, mylić się, zmieniać zdanie, nieobdarzone wszystkimi cechami pozytywnymi lub uważanymi za takie w danym systemie społecznym"12 (ibidem: 318 ).

W latach 1976-1994 oficyna opublikowała 57 książek, w tym 27 pomysłu lub autorstwa Bruela (Le Dro 2013: 142). Z wydawnictwem współpracowali znakomici francuscy ilustratorzy, przede wszystkim Nicole Claveloux i Anne Bozellec, ale też Pef, Katy Couprie czy Paul Cox. Praca nad książkami przebiegała w sposób nietypowy, bo ich projekty przedstawiano dzieciom i sprawdzano, czy sposób opowiedzenia historii za pomocą tekstu i ilustracji budzi ich zainteresowanie.

\footnotetext{
${ }^{9}$ „Nous voulons rompre avec ces livres [...] où après des révoltes fugaces, les conclusions obligent à rentrer dans le rang".

${ }^{10},[\ldots]$ c'était faire un autre livre, un livre d'intervention à la fois pour les enfants, et pour les adultes, un livre où chacun, quel que soit son âge, puisse trouver matière à rêver, à penser, à s'insurger, un livre qui ne fasse plus l'innocent".

${ }^{11}$ „Nous parlerons de la tendresse, de l'angoisse, des jouissances, du divorce, de la douleur, de l'anormalité, de l'eau, du feu, de la vie, de la mort... plus que des gentils papillons ou des vilains petits canards".

${ }^{12},[\ldots]$ des personnages denses, conflictuels, ambigus, sulfureux, capables de douter, de se tromper, de revenir en arrière, de n'être pas forcément porteurs de toutes les valeurs positives ou prétendues telles, d'un système social".
} 


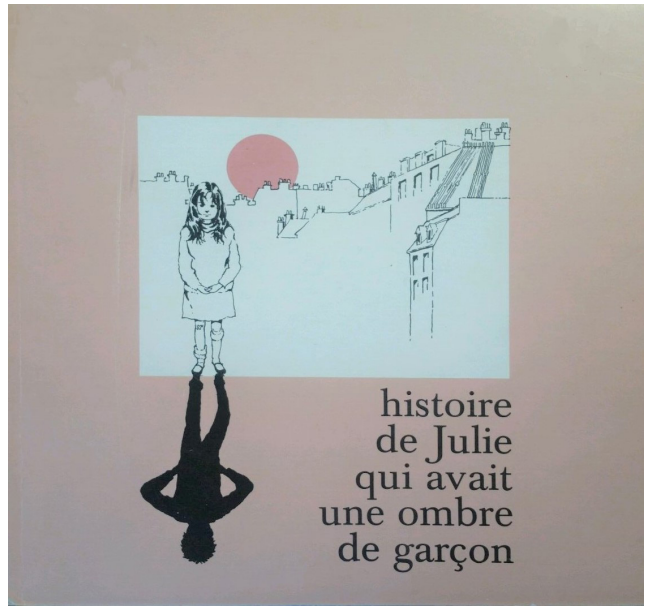

Il. 5. Okładka książki Histoire de Julie qui avait une ombre de garçon

Christiana Bruela i Anne Galland ilustrowanej przez Anne Bozellec z 1976 roku

Punktem wyjścia dla wielu opowiadanych historii były zwykłe, codzienne wydarzenia, na przykład w książce Un jour de lessive (1987, Dzień prania) rozwieszone na sznurze w letni dzień pranie staje się dla małego chłopca teatrem wyobraźni, w którym spotyka rycerzy, dzikie zwierzęta, skrzaty. Crapougneries (1986, Świństewka) to rodzaj katalogu zakazanych, nieakceptowanych przyjemności dzieciństwa: zabaw w łazience i w deszczu, obżerania się i wielu innych (zob. Duborgel 1982). Książka Les chatouilles (1981, Gilgotki), składająca się z ciągu ilustracji chłopca i dziewczynki, łaskoczących się przed snem, przyjęta została przez czytelników z mieszanymi uczuciami ze względu na aluzje do dziecięcej seksualności, których się w niej dopatrywano (Rolland 2013).

Wydawca - w roli pomysłodawcy publikowanych książek - nie wahał się też podejmować trudne tematy, ujmując je w zaskakujący czasem sposób. Bohaterka książki Lison et l'eau dormante (1978, Lison i śpiąca woda) ma prawie osiem lat, ale chciałaby ich mieć znowu pięć, jak wtedy, gdy jej rodzice jeszcze się kochali. Teraz udają, że wszystko jest w porządku, jednak dziewczynka jest zmęczona tą grą pozorów, ucieka w świat wyobraźni, a wreszcie podejmuje próbę samobójstwa. Bohaterka Venise n'est pas trop loin (1986, Wenecja nie jest zbyt daleko), mająca lat trzynaście (czy też - jak sama twierdzi - „prawie piętnaście!”), wpada w panikę po przegraniu w karty z dorosłym nieznajomym dwóch godzin swojego życia.

\section{Wpływ nowatorskich książek obrazkowych}

Książki obrazkowe, które ukazały się we Francji na przełomie lat sześćdziesiątych i siedemdziesiątych nakładem małych awangardowych oficyn, przyczyniły się do podjęcia we Francji społecznej dyskusji na temat sposobów rozumienia pojęć 
dziecka, dzieciństwa i literatury dla dzieci. Przetarły tym samym szlaki dla wielu odważnych, nowatorskich książek dla dzieci, które powstały w kolejnych latach. Nie pozostały też bez wpływu na ofertę dużych, tradycyjnych wydawnictw francuskich i na publikowaną przez nie literaturę dla młodych czytelników. Zasygnalizował to już w 1973 roku Maurice Fleurent $\mathrm{z}$ wydawnictwa Hachette, największego wówczas gracza na rynku książki dla dzieci we Francji, mówiąc do Ruy-Vidala: „Wy jesteście jak lodołamacz, a Hachette pójdzie za wami”'13 (Ruy-Vidal 1973: 92). Dynamizm awangardowych wydawców literatury dla dzieci i młodzieży z przełomu dekad stał się też przeciwwagą dla postępującej komercjalizacji książki i przyczynił się do restrukturyzacji całego rynku książki we Francji (Mollier 2015: 378).

Zaprezentowany w niniejszym artykule przegląd założeń i dokonań nurtu awangardowej książki obrazkowej powstającej do przełomu lat sześćdziesiątych i siedemdziesiątych XX wieku we Francji miał na celu pokazanie, jak bardzo nieuzasadniona była rozpowszechniona w tym okresie w Polsce opinia o francuskiej literaturze dla dzieci i młodzieży. W tym samym czasie, gdy polscy krytycy oceniali ją jako tradycyjną, płytką i zachowawczą, francuska literatura dla niedorosłych bezkompromisowo mierzyła się $\mathrm{z}$ nowymi tematami i odważnie eksperymentowała $z$ nowymi formami plastycznymi, czego efektem stały się nowatorskie książki obrazkowe.

\section{Literatura}

Agulhon M., Schor R., Nouschi A., 1995, La France de 1940 à nos jours, Paris: Nathan.

Beckett S.L., 2012, Crossover Picturebooks. A Genre for All Ages, New York-London: Routledge.

Beckett S.L., 2015, Manifestations of the avant-garde and its legacy in French children's literature [w:] Children's Literature and the Avant-Garde, eds E. Druker, B. KummerlingMeibauer, Philadelphia: John Benjamins Publishing Company.

Boulaire C., 2008, La littérature en album est-elle (encore) subversive? [w:] L'album contemporain pour la jeunesse, nouvelles formes, nouveaux lecteurs?, dir. Ch. Connan-Pintado, F. Gaiotti, B. Poulou, Bordeaux: Presses universitaires de Bordeaux.

Bouvaist J.M., Boin J.G., 1989, Du printemps des éditeurs à l'âge de raison: Les nouveaux éditeurs en France (1974-1988), Paris: La Documentation française - Sofedis.

Cackowska M., 2009-2010, Czym jest książka obrazkowa? O pojmowaniu ksiażki obrazkowej dla dzieci w Polsce, cz. 1: „Ryms” 2009, nr 5; cz. 2: „Ryms” 2009, nr 6; cz. 3: „Ryms” 2009/2010, nr 8.

Cackowska M., 2017, Współczesna książka obrazkowa - pojęcie, typologia, badania, teorie, konteksty, dyskursy [w:] Ksiażka obrazkowa. Wprowadzenie, red. M. Cackowska, H. Dymel-Trzebiatowska, J. Szyłak, Poznań: Instytut Kultury Popularnej.

Cackowska M., Wincencjusz-Patyna A., 2017, Polska Szkoła Ksiażki Obrazkowej, proj. i oprac. graf. G. Lange, Gdańsk: Nadbałtyckie Centrum Kultury.

\footnotetext{
${ }^{13}$ „Vous êtes le brise-glace et Hachette passera derrière".
} 
Dolto F., 11-17.12.1972, Littérature enfantine, attention danger!, interview de Jannick Jossin, „L'Express".

Duborgel B., 1982, Figures d'enfance, visages d'espace, horizons mythiques. Du «Struwwelpeter» au «Sourire qui mord» [w:] Espaces en representation, dir. B. Duborgel, SaintÉtienne: CIEREC.

Heywood S., 2018, Le “68 des enfants: introduction, „Strenæ”, nr 13.

Kuliczkowska K., 1957, O strachach i o... Martali, „Nowe Książki”, nr 22.

Le Dro J.C., 2013, Bruel, Christian [w:] Dictionnaire du livre de jeunesse, dir. I. NièresChevrel, J. Perrot, Paris: Éditions du Cercle de la Librairie.

Lévêque M., 2011, Écrire pour la jeunesse en France et en Allemagne dans l'entre-deuxguerres, Rennes: Presses universitaires de Rennes.

Mollier J.Y., 2015, Une autre histoire de l'édition française, Paris: La Fabrique.

Nières-Chevrel I., 2003, François Ruy-Vidal et la révolution de l'album pour enfants dans les années 1970 [w:] L'image pour enfants: pratiques, normes, discours (France et pays francophones, $X V I^{e}-X X^{e}$ siècles), dir. A. Renonciat, Poitiers: La Licorne.

Nières-Chevrel I., 2009, Introduction à la littérature de jeunesse, Paris: Didier Jeunesse.

Nières-Chevrel I., 2010, La réception française de Max et les maximonstres: retour sur une légende, „Strenæ”, nr 1.

Nowakowska O., 1968, Światowa książka dziecięca w Polsce i polska książka w świecie [w:] Kim jesteś, Kopciuszku, czyli o problemach współczesnej literatury dla dzieci i młodzieży, red. S. Aleksandrzak, Warszawa: Nasza Księgarnia.

Paprocka N., 2018, Sto lat przekładów dla dzieci i młodzieży w Polsce. Francuska literatura dla młodych czytelników, jej polscy wydawcy i ich strategie (1918-2014), Kraków: Universitas.

Piquard M., 2005, L'édition pour la jeunesse en France de 1945 à 1980, Villeurbanne: Presses de l'Enssib.

Piquard M., 2010, Robert Delpire, un précurseur dans l'édition pour la jeunesse des années 1950-1970, „Strenæ”, nr 1.

Prince N., 2015, La littérature de jeunesse: pour une théorie littéraire, Paris: Armand Colin.

Rolland A., 2013, Est-ce que ça vous chatouille?, Ricochet, https://www.ricochet-jeunes.org/ articles/est-ce-que-ca-vous-chatouille [dostęp: 20.02.2019].

Ruy-Vidal F. 1973, Philosophie d'un jeune éditeur 1972 [w:] Les exigences de l'image, dir. D. Escarpit, Paris: Magnard.

Soriano M., 1975, Guide de littérature pour la jeunesse, Paris: Flammarion.

Van Der Linden S., 2009, L'album, un suport artistique? [w:] La Littérature de jeunesse en question(s), dir. N. Prince, Rennes: Presses Universitaires de Rennes.

Van Der Linden S., 2013, L'albo illustrato in Francia dopo gli anni Sessanta: uno scenario caleidoscopico [w:] Bologna: cinquant'anni di libri per ragazzi da tutto il mondo, a cura di G. Grilli, Bologna: Bononia University Press.

Vergez-Sans C., 2016, François Ruy-Vidal: les collections en question. L'apport des archives, „Strenæ", nr 11.

Wincencjusz-Patyna A., 2008, Stacja ilustracja. Polska ilustracja książkowa 1950-1980. Artystyczne kreacje i realizacje, Wrocław: Akademia Sztuk Pięknych im. Eugeniusza Gepperta-Instytut Historii Sztuki Uniwersytetu Wrocławskiego. 


\section{Materiały źródłowe}

Alençon M. d', 1939, Tout en soie, cochon aérodynamique, il. F. Themerson, Paris: Flammarion.

Alençon M. d', 1939, Tricoti Tricota, il. F. Themerson, Paris: Flammarion.

Bertall, 1867, Mademoiselle Marie Sans-Soin, Paris: Hachette.

Bruel C., 1981, Les chatouilles, il. A. Bozellec, Paris: le Sourire qui mord.

Bruel C., 1986, Venise n'est pas trop loin, il. A. Bozellec, Paris: le Sourire qui mord.

Bruel C., 1987, Un jour de lessive, il. A. Bozellec, Paris: le Sourire qui mord.

Bruel C., Galland A., 1976, Histoire de Julie qui avait une ombre de garçon, il. A. Bozellec, Paris: le Sourire qui mord.

Bruel C., Galland A., 1978, Lison et l'eau dormante, il. A. Bozellec, Paris: le Sourire qui mord.

Brunhoff J. de, 1931, Histoire de Babar, le petitéléphant, Paris: Éditions du Jardin des modes. Duras M., 1971, Ah! Ernesto, Paris: Harlin Quist.

Édy-Legrand, 1919, Macao et Cosmage ou L'expérience du bonheur, Paris: Nouvelle Revue française.

François A., 1955, Les larmes de crocodile, Paris: Delpire.

Hoffmann H., 1860, Pierre l'ébouriffé, joyeuses histoires et images drôlatiques pour les enfants de 3 à 6 ans, Paris: L. Hachette.

Hoffmann H., 1971, Pierre l'ébouriffé: histoires pas très drôles, d'un passé toujours présent, adapt. F. Ruy-Vidal, il. C. Lapointe, trad. S. Holzlehner et L. Lapointe, Boissy-St-Léger: François Ruy-Vidal et Harlin Quist.

Ionesco E., 1969, Conte numéro 1: pour enfants de moins de trois ans, il. E. Delessert, Paris: Harlin Quist.

Ionesco E., 1970, Conte numéro 2: pour enfants de moins de trois ans, il. E. Delessert, Paris: Harlin Quist.

Ionesco E., 1971, Conte numéro 3: pour enfants de moins de trois ans, il. P. Corentin, Paris: Harlin Quist.

Monreal G., 1970, Alala: les télémorphoses, il. N. Claveloux, Paris: Harlin Quist.

Roy C., 1964, C'est le bouquet!, il. A. Le Foll, Paris: Delpire.

Ruffault C., Bruel C., 1981, Crapougneries, il. A. Bozellec, Paris: le Sourire qui mord.

Ségur S. de, 1970, La forêt des lilas, il. N. Claveloux, Paris: Harlin Quist.

Sendak M., 1967, Max et les Maximonstres, Paris: Delpire.

Stahl P.J., 1862, Une journée de Mademoiselle Lili, il. L. Frølich, Paris: J. Hetzel et Cie.

Turin A., Bosnia N., 1975, Rose bombonne, Paris: Éditions des Femmes.

Turin A., Bosnia N., 1976, Clémentine s'en va, Paris: Éditions des Femmes.

\section{Streszczenie}

Niniejszy artykuł zawiera omówienie założeń i dokonań nieznanego w Polsce nurtu awangardowej książki obrazkowej powstającej na przełomie lat sześćdziesiątych i siedemdziesiątych XX wieku we Francji i publikowanej przez niezależne oficyny, takie jak Robert Delpire, Harlin Quist, Éditions des Femmes czy Le Sourire qui mord. Celem przedstawionego zarysu jest nie tylko zapoznanie polskiego czytelnika z tym rodzajem twórczości 
artystycznej, ale też pokazanie, jak bardzo nieuzasadniona była rozpowszechniona w tym okresie w Polsce opinia o francuskiej literaturze dla dzieci i młodzieży jako o zachowawczej i płytkiej.

\section{Słowa kluczowe}

francuska książka obrazkowa, książka dla dzieci i młodzieży, awangarda

\section{Summary}

Not so long ago in France...

The year 1968 and the French revolution in the field of picturebooks

In the present article, we discuss the assumptions and achievements of the avant-garde trend, unknown in Poland, that took place in France at the turn of the 60' and 70' of the XX century in the field of picturebooks. The picturebooks were published by independent houses such as Robert Delpire, Harlin Quist, Éditions des Femmes and Le Sourire qui mord. The purpose of this outline is not only to present this type of artistic creation to the Polish reader, but also to show how unfounded was the widespread opinion on French children's literature in Poland, where it was usually seen as conservative and shallow.

\section{Keywords}

French picturebooks, children's literature, avant-garde 